\title{
The volcano-tectonic evolution of the Miocene Santa Lucía Volcano, Boaco district, Nicaragua
}

\author{
David BURIÁNEK ${ }^{1 *}$, Petr HRADECKÝ ${ }^{2}$ \\ ${ }^{1}$ Czech Geological Survey, Leitnerova 22,658 59 Brno, Czech Republic; david.burianek@geology.cz \\ ${ }^{2}$ Czech Geological Survey, Klárov 3, 11821 Prague 1, Czech Republic; petr.hradecky@geology.cz \\ ${ }^{*}$ Corresponding author
}

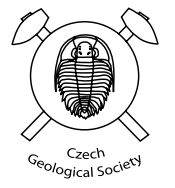

\begin{abstract}
The present-day Santa Lucía caldera is an erosional relic of a Late Oligocene to Early Miocene stratoshield volcano located in the south-western part of the Chortis Block in Central Nicaragua. Six main lithological units were recognized: (Unit I) dacitic ignimbrite of Boaco type, which represents the basement of the Santa Lucía caldera; (Unit II) dacitic ignimbrite of Fonseca type, locally intercalated with epiclastic and dacitic lavas; (Unit III) "lower" andesite lavas; (Unit IV) blocky, lithic-rich pyroclastic flow deposits, (Unit V) "upper" andesite and basalt lavas, and (Unit VI) epiclastic rocks (lahar deposits).

On the basis of field mapping, petrological and geochemical data, a new model for the evolution of the Santa Lucía Volcano is presented. The first stage consisted of a series of strong Sub-Plinian eruptions, which produced thick ignimbrite units. These events destroyed the pre-existing volcanic edifice. The second stage was dominated by large explosive eruptions producing mainly non-welded dacitic-andesitic ignimbrites. The next resulted in the formation of andesitic lava flows and minor tephra fall-out deposits, covered by voluminous basaltic lavas. Lahars probably triggered by volcanic and/or seismic events represent the final stage of volcanic activity. From the Miocene onwards, volcanic rocks became deeply weathered and locally eroded. Strongly weathered rocks are susceptible to landslides, and surficial modification by post-volcanic slope movements is observed on the slopes of the Santa Lucía Volcano.

Identification of the lithological units and their comparison with wider Tertiary volcanic areas in Central Nicaragua will contribute to the knowledge of the regional volcanic stratigraphy and evolution.
\end{abstract}

Keywords: caldera, volcanostratigraphy, ignimbrite, Santa Lucia Volcano, Nicaraguan Interior Highlands Received: 2 November 2010; accepted: 3 March 2011; handling editor: V. Rapprich

\section{Introduction}

Tertiary volcanic rocks forming the Nicaraguan Interior Highlands have been generally subdivided into three main units (Weyl 1980): The Matagalpa Group (Oligocene-Miocene) and the Lower and Upper Coyol Group (Miocene). All volcanic activity is believed to have taken place between 25 and 17 Ma (Elming and Rasmussen 1997). Ehrenborg (1996) subdivided the Coyol Group in the Santa Lucía region into three units: Santa Lucía, La Libertad and Las Maderas. This simple subdivision facilitates the lithological correlation but disregards the differences between individual volcanic centres.

Lithologically, the Santa Lucía caldera may represent the upper part of the Coyol Group, referred to as the Santa Lucía Unit (Ehrenborg 1996). This unit is very complex, being dominated by ignimbrites, lava flows, lahars, volcanic conglomerates and pyroclastic fall deposits of basaltic to andesitic composition. Minor lava flows, pyroclastic and epiclastic deposits, and intracaldera domes of rhyolitic to dacitic composition also occur (Ehrenborg 1996).
The Santa Lucía caldera is located in the central part of Nicaragua. Similarly to the surrounding volcanic centres (Las Lajas, La Luna and San Lorenzo), it represents an erosional remnant of a Miocene stratoshield (Ehrenborg 1996), according to subdivision of Cas and Wright (1987). These types of volcanoes show some features of stratovolcanoes but exhibit wide bases, usually formed by voluminous accumulations of silicic ignimbrites. We describe the lithology of the Santa Lucía Volcano, reconstruct its geological history and compare it with the surrounding volcanoes. All new data were acquired during new detailed fieldwork, including mapping.

\section{Geological setting}

The Central American Volcanic Arc (CAVA) developed with the incipient subduction of the Farallon Plate beneath the northern Central America in the Late Cretaceous (Duncan and Hargraves 1984; Tyburski et al. 1991; Plank et al. 2002; Carr et al. 2003; Jordan et al. 2007a, b). Throughout the Neogene, the landscape of 
Tab. 1 List of studied rock samples

\begin{tabular}{|c|c|c|c|c|c|}
\hline Volcano & Sample & Unit & Rock & $\mathrm{N}$ coordinate & E coordinate \\
\hline \multirow[t]{13}{*}{ Santa Lucia } & D273 & I & Ignimbrite & 12.468028 & -85.664139 \\
\hline & H143 & II & Ignimbrite & 12.472806 & -85.722111 \\
\hline & D256 & II & Ignimbrite & 12.459611 & -85.575417 \\
\hline & D045 & II & Dacite & 12.510518 & -85.715826 \\
\hline & H035 & III & Andesite & 12.502830 & -85.650687 \\
\hline & D204 & III & Andesite & 12.494750 & -85.668722 \\
\hline & D090 & $\mathrm{V}$ & Dacite & 12.555484 & -85.723009 \\
\hline & D020 & V & Andesite & 12.552851 & -85.685809 \\
\hline & D092 & V & Basalt & 12.541634 & -85.707559 \\
\hline & D083 & $\mathrm{V}$ & Basalt & 12.510601 & -85.662409 \\
\hline & D136 & V & Basalt & 12.470783 & -85.681783 \\
\hline & D069 & VI & Trachyte & 12.538651 & -85.660076 \\
\hline & L001 & VI & Dacite & 12.543201 & -85.658043 \\
\hline \multirow[t]{3}{*}{ Las Lajas } & LA001 & $\mathrm{V}$ & Basaltic andesite & 12.165030 & -85.425870 \\
\hline & LA003 & V & Andesite & 12.165030 & -85.425880 \\
\hline & H124B & V & Basalt & 12.274500 & -85.715333 \\
\hline \multirow[t]{2}{*}{ La Luna } & D275 & $\mathrm{V}$ & Andesite & 12.605111 & -85.718500 \\
\hline & D245 & $\mathrm{V}$ & Basalt & 12.659750 & -85.703306 \\
\hline
\end{tabular}

central Nicaragua (Nicaraguan Interior Highlands) was formed by frequent eruptions of mafic and felsic effusive and pyroclastic rocks on the continental crust of the Chortis Block. Erosional relics of volcanic topography reach elevations exceeding $1 \mathrm{~km}$.

Volcanic rocks in Nicaragua can be divided into two main areas according to their age and location. Quaternary and Tertiary volcanic areas are partly separated by the SE-NW-trending Nicaraguan Depression (McBirney and Williams 1965), which is now considered a Neogene intra-arc basin (Funk et al. 2009). Quaternary volcanic rocks are predominantly located west of the Nicaraguan Depression whereas Tertiary volcanic units prevail to the east.

The study area is situated in the Boaco district, in the south-western part of the Nicaraguan Interior Highlands (Fig. 1a). This area structurally belongs to the southern part of the Chortis Block (Rogers et al. 2007), which is mostly covered by Miocene to Pliocene volcanic products.

In the Santa Lucía area (Fig. 1b), Oligocene-Miocene Matagalpa Group has been described as composed of acid ignimbrite strata and rhyolitic to dacitic lavas (Ehrenborg 1996). This division, however, does not correspond to the regional lithological description of this group, as introduced by Hodgson (1972). Matagalpa Group should consist mainly of basaltic and andesitic lavas with subordinate ignimbrites and high degree of weathering and/ or hydrothermal alteration (Hodgson 1972). This group can be correlated with the Morazán Unit in El Salvador and Guatemala (Hradecký 2006).

The Miocene Coyol Group in the study area consists mainly of intermediate to basic lavas, breccias, lahar deposits and locally of pyroclastic rocks. Volcanism of this type developed on thick acid ignimbritic sequences (rhyolite shields and domes; Cas and Wright 1987). Both groups record a relatively continuous volcanic production and migration of eruptive centres. Therefore, volcanic rocks of the individual, partly contemporaneous sources interfinger all over the region. Hradecký (2006) paralleled the two parts of the Coyol Group (Lower and Upper) with the Lower and the Upper Somoto units, respectively, which have been defined in the Somoto region (Ehrenborg 1996). In more regional context these can be correlated with the Padre Miguel and San Jacinto groups in Honduras and Guatemala.

Three volcanoes surround the Santa Lucía Volcano: La Luna, Las Lajas and San Lorenzo. During and after the period of main volcanic activity, some of them were destroyed by erosion and/or tectonics (Hradecký et al. 2008).

\section{Analytical methods}

Electron microprobe analyses (EMPA) were performed on the Cameca SX-50 instrument, in the Joint Laboratory of Electron Microscopy and Microanalysis of the Masaryk University and the Czech Geological Survey (Brno, Czech Republic). Wavelength-dispersion mode with a beam diameter of 4-5 $\mu \mathrm{m}$, an accelerating potential of $15 \mathrm{kV}$ and sample current of $20 \mathrm{nA}$ were used for $\mathrm{Si}, \mathrm{Al}, \mathrm{Ti}, \mathrm{Fe}, \mathrm{Mn}, \mathrm{Mg}, \mathrm{Ca}, \mathrm{Na}$ and $\mathrm{K}$. Higher current of $40 \mathrm{nA}$ was employed for $\mathrm{Zn}, \mathrm{F}$ and P; counting time was $20 \mathrm{~s}$ for all elements. The following standards were used 


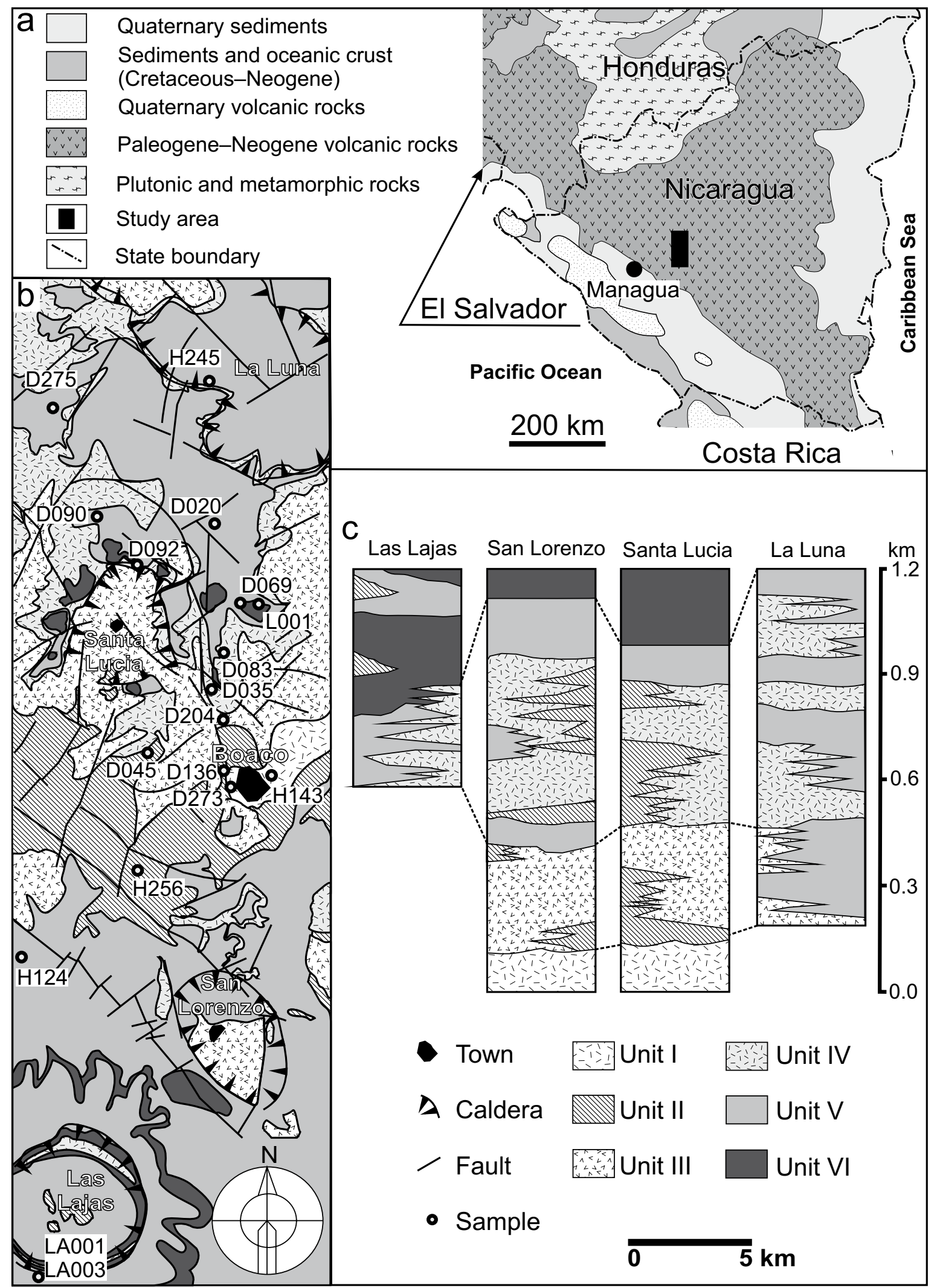

Fig. 1a Simplified geological map of the northern Central America showing the location of the study area (based on map of Weyl 1980); $\mathbf{b}-$ simplified geological map of the study area with sample locations (Tab. 1); $\mathbf{c}$ - lithological columns for the studied volcanoes (adapted after Buriánek et al. 2008a, b). 
Tab. 2 Representative major- and trace-element whole-rock chemical analyses (wt. \% and ppm, respectively)

\begin{tabular}{|c|c|c|c|c|c|c|c|c|c|c|c|c|c|c|}
\hline Volcano & & & & & Sant & a Lucia & & & & & & Las Lajas & & La Luna \\
\hline Sample & H143 & D256 & D045 & $\mathrm{H} 035$ & D090 & D020 & D092 & D083 & D069 & L001 & LA001 & LA003 & H124B & D245 \\
\hline $\begin{array}{l}\text { Unit } \\
\text { wt. } \%\end{array}$ & II & II & II & III & V (lower) & V (lower) & V (upper) & V (upper) & VI & VI & $\mathrm{V}$ & $\mathrm{V}$ & V & V \\
\hline $\mathrm{SiO}_{2}$ & 72.34 & 61.16 & 70.30 & 64.44 & 67.80 & 59.00 & 48.97 & 50.44 & 63.32 & 61.74 & 56.52 & 62.81 & 54.95 & 53.49 \\
\hline $\mathrm{TiO}_{2}$ & 0.29 & 0.97 & 0.20 & 0.73 & 0.40 & 0.90 & 1.10 & 1.08 & 0.80 & 0.77 & 0.86 & 0.73 & 0.98 & 0.93 \\
\hline $\mathrm{Al}_{2} \mathrm{O}_{3}$ & 13.04 & 17.30 & 15.79 & 16.27 & 15.37 & 17.21 & 18.40 & 17.99 & 15.69 & 15.75 & 17.42 & 17.01 & 17.15 & 19.31 \\
\hline $\mathrm{Fe}_{2} \mathrm{O}_{3}$ & 2.31 & 6.38 & 2.11 & 4.69 & 3.40 & 6.95 & 11.52 & 10.10 & 5.41 & 4.99 & 8.36 & 4.93 & 9.09 & 8.18 \\
\hline $\mathrm{MnO}$ & 0.05 & 0.15 & 0.03 & 0.10 & 0.11 & 0.16 & 0.23 & 0.16 & 0.17 & 0.25 & 0.16 & 0.14 & 0.16 & 0.19 \\
\hline $\mathrm{MgO}$ & 0.33 & 0.56 & 0.18 & 0.51 & 0.55 & 1.61 & 5.13 & 4.05 & 1.15 & 1.38 & 2.99 & 1.04 & 3.03 & 2.65 \\
\hline $\mathrm{CaO}$ & 1.58 & 4.40 & 1.80 & 3.18 & 2.70 & 5.13 & 10.21 & 9.22 & 3.20 & 4.53 & 6.97 & 4.22 & 6.80 & 8.27 \\
\hline $\mathrm{Na}_{2} \mathrm{O}$ & 1.85 & 4.80 & 5.00 & 4.45 & 3.84 & 4.54 & 2.70 & 3.05 & 4.39 & 3.69 & 3.27 & 4.13 & 3.21 & 3.91 \\
\hline $\mathrm{K}_{2} \mathrm{O}$ & 5.61 & 2.05 & 2.47 & 2.77 & 2.95 & 1.73 & 0.70 & 0.84 & 3.47 & 3.19 & 1.49 & 2.49 & 1.51 & 1.29 \\
\hline $\mathrm{P}_{2} \mathrm{O}_{5}$ & 0.15 & 0.36 & 0.10 & 0.25 & 0.11 & 0.38 & 0.24 & 0.30 & 0.32 & 0.38 & 0.20 & 0.31 & 0.27 & 0.35 \\
\hline $\mathrm{Cr}_{2} \mathrm{O}_{3}$ & $<0.002$ & $<0.002$ & $<0.002$ & $<0.002$ & $<0.002$ & $<0.002$ & 0.005 & 0.007 & 0.002 & $<0.002$ & 0.002 & $<0.002$ & $<0.002$ & 0.008 \\
\hline LOI & 2.4 & 1.7 & 1.9 & 2.4 & 2.6 & 2.2 & 0.5 & 2.6 & 1.8 & 3.1 & 1.5 & 2.0 & 2.6 & 1.2 \\
\hline Sum & 99.92 & 99.85 & 99.85 & 99.78 & 99.82 & 99.81 & 99.72 & 99.82 & 99.73 & 99.76 & 99.74 & 99.81 & 99.71 & 99.79 \\
\hline ppm & & & & & & & & & & & & & & \\
\hline $\mathrm{Rb}$ & 61.9 & 36.2 & 41.6 & 57.1 & 63.2 & 35.2 & 13.2 & 8.2 & 67.1 & 67.1 & 23.4 & 37.7 & 27.7 & 18.7 \\
\hline Cs & 0.6 & 0.5 & 0.4 & 1.0 & 1.6 & 0.6 & $<0.1$ & $<0.1$ & 1.5 & 1.5 & 1.0 & 0.6 & 1.0 & 0.1 \\
\hline $\mathrm{Sr}$ & 139.1 & 406.3 & 271.1 & 361.7 & 318.5 & 478.1 & 531.7 & 518.9 & 376.3 & 454.9 & 472.9 & 380.1 & 451.9 & 600.6 \\
\hline $\mathrm{Ba}$ & 667 & 720 & 816 & 886 & 981 & 548 & 253 & 353 & 1041 & 921 & 757 & 1360 & 1199 & 481 \\
\hline $\mathrm{Nb}$ & 2.2 & 7.5 & 6.2 & 6.7 & 5.2 & 4.4 & 2.4 & 3.1 & 6.4 & 5.9 & 3.0 & 5.5 & 3.7 & 3.2 \\
\hline $\mathrm{Ta}$ & $<0.1$ & $<0.1$ & 0.4 & 0.4 & 0.4 & 0.3 & 0.1 & 0.3 & 0.4 & 0.4 & 0.2 & 0.3 & $<0.1$ & $<0.1$ \\
\hline $\mathrm{Zr}$ & 123.5 & 150.1 & 194.1 & 203.9 & 181.7 & 131.2 & 68.5 & 84.3 & 201.7 & 174.5 & 84.1 & 155.2 & 106.1 & 120.5 \\
\hline Hf & 3.5 & 4.2 & 5.4 & 6.6 & 5.8 & 4.1 & 2.3 & 2.7 & 6.1 & 5.2 & 2.6 & 4.7 & 3.0 & 3.3 \\
\hline $\mathrm{Ga}$ & 10.5 & 18.0 & 17.8 & 17.7 & 14.5 & 17.3 & 17.5 & 18.9 & 15.7 & 14.9 & 18.8 & 18.6 & 16.9 & 18.9 \\
\hline Th & 1.9 & 2.0 & 2.6 & 3.0 & 3.2 & 1.8 & 0.5 & 1.0 & 3.7 & 3.7 & 1.1 & 2.5 & 1.4 & 1.3 \\
\hline $\mathrm{U}$ & 0.8 & 1.0 & 1.0 & 1.2 & 1.5 & 0.8 & 0.4 & 0.5 & 1.7 & 1.5 & 0.5 & 0.8 & 0.7 & 0.6 \\
\hline $\mathrm{Ni}$ & 0.7 & 0.2 & 0.3 & 0.6 & 0.5 & 2.8 & 16.0 & 17.2 & 0.6 & 1.1 & 2.8 & 1.0 & 0.8 & 2.3 \\
\hline $\mathrm{Co}$ & 4.2 & 7.3 & 0.6 & 4.1 & 3.5 & 11.0 & 32.5 & 29.0 & 6.2 & 7.6 & 20.7 & 7.9 & 18.8 & 18.4 \\
\hline V & 28 & 68 & $<8$ & 20 & 15 & 84 & 289 & 273 & 39 & 38 & 202 & 53 & 218 & 186 \\
\hline $\mathrm{Sc}$ & 6 & 20 & 3 & 14 & 6 & 18 & 32 & 28 & 14 & 14 & 26 & 15 & 26 & 22 \\
\hline $\mathrm{Pb}$ & 1.7 & 2.1 & 0.5 & 2.7 & 0.7 & 2.2 & 0.6 & 1.4 & 0.8 & 0.5 & 0.4 & 2.2 & 0.6 & 1.1 \\
\hline $\mathrm{Cu}$ & 8.3 & 11.0 & 1.2 & 1.6 & 6.2 & 20.8 & 111.6 & 74.1 & 10.1 & 7.3 & 59.1 & 26.2 & 29.9 & 44.6 \\
\hline $\mathrm{Zn}$ & 32 & 76 & 41 & 62 & 34 & 67 & 49 & 46 & 35 & 34 & 34 & 63 & 33 & 45 \\
\hline W & $<0.5$ & $<0.5$ & $<0.5$ & $<0.5$ & 10.0 & $<0.5$ & $<0.5$ & $<0.5$ & $<0.5$ & $<0.5$ & $<0.5$ & $<0.5$ & $<0.5$ & $<0.5$ \\
\hline Mo & 0.5 & 0.7 & 0.6 & 0.8 & 0.3 & 0.7 & 0.5 & 0.5 & 0.3 & 0.2 & 0.2 & 0.5 & 0.2 & 0.7 \\
\hline $\mathrm{Sn}$ & $<1$ & $<1$ & 5 & 3 & 2 & 4 & 4 & 4 & 5 & 2 & 1 & 5 & $<1$ & $<1$ \\
\hline $\mathrm{Be}$ & 1 & 2 & 2 & 2 & 2 & 2 & $<1$ & 1 & 1 & $<1$ & $<1$ & 3 & 2 & 1 \\
\hline $\mathrm{La}$ & 5.8 & 17.2 & 18.3 & 22.5 & 21.3 & 15.5 & 8.2 & 10.3 & 25.6 & 21.9 & 14.3 & 15.1 & 13.4 & 12.2 \\
\hline $\mathrm{Ce}$ & 9.9 & 34.9 & 40.0 & 44.6 & 39.1 & 34.6 & 17.7 & 22.7 & 50.4 & 47.0 & 21.2 & 34.2 & 28.5 & 26.9 \\
\hline $\operatorname{Pr}$ & 1.21 & 5.66 & 5.69 & 7.42 & 6.15 & 5.26 & 3.03 & 3.75 & 7.61 & 6.80 & 5.12 & 5.18 & 4.52 & 4.21 \\
\hline $\mathrm{Nd}$ & 4.6 & 28.3 & 24.8 & 31.4 & 24.0 & 24.6 & 14.6 & 17.6 & 32.0 & 29.8 & 24.1 & 22.8 & 20.8 & 19.1 \\
\hline $\mathrm{Sm}$ & 0.80 & 6.84 & 4.90 & 6.78 & 4.96 & 5.71 & 3.49 & 4.21 & 7.15 & 6.07 & 5.87 & 5.75 & 5.11 & 4.74 \\
\hline $\mathrm{Eu}$ & 0.41 & 1.96 & 1.23 & 2.12 & 1.33 & 1.78 & 1.27 & 1.34 & 1.90 & 1.76 & 1.88 & 1.50 & 1.45 & 1.51 \\
\hline $\mathrm{Gd}$ & 0.97 & 7.47 & 4.76 & 6.82 & 4.64 & 5.99 & 3.84 & 4.67 & 6.92 & 5.95 & 6.87 & 6.30 & 5.39 & 4.98 \\
\hline $\mathrm{Tb}$ & 0.19 & 1.19 & 0.81 & 1.20 & 0.77 & 1.01 & 0.62 & 0.81 & 1.06 & 1.02 & 1.12 & 1.11 & 0.91 & 0.83 \\
\hline Dy & 1.37 & 6.99 & 4.55 & 6.23 & 4.75 & 5.70 & 3.75 & 4.46 & 6.46 & 5.50 & 6.60 & 6.47 & 5.33 & 4.63 \\
\hline Ho & 0.31 & 1.50 & 1.04 & 1.33 & 1.02 & 1.09 & 0.84 & 0.92 & 1.38 & 1.16 & 1.26 & 1.29 & 1.11 & 0.97 \\
\hline $\mathrm{Er}$ & 1.17 & 4.57 & 3.06 & 3.79 & 2.90 & 3.26 & 2.29 & 2.75 & 3.84 & 3.31 & 3.85 & 4.00 & 3.32 & 3.01 \\
\hline $\mathrm{Tm}$ & 0.20 & 0.71 & 0.58 & 0.64 & 0.50 & 0.54 & 0.34 & 0.42 & 0.66 & 0.53 & 0.58 & 0.62 & 0.50 & 0.44 \\
\hline $\mathrm{Yb}$ & 1.49 & 4.49 & 3.40 & 3.71 & 3.08 & 3.35 & 2.20 & 2.49 & 4.04 & 3.32 & 3.56 & 3.95 & 3.26 & 2.80 \\
\hline $\mathrm{Lu}$ & 0.25 & 0.72 & 0.60 & 0.61 & 0.51 & 0.54 & 0.33 & 0.40 & 0.62 & 0.57 & 0.55 & 0.63 & 0.50 & 0.44 \\
\hline $\mathrm{Y}$ & 10.3 & 45.7 & 32.0 & 38.9 & 27.3 & 33.7 & 21.6 & 27.6 & 38.6 & 35.5 & 38.8 & 40.7 & 30.9 & 27.7 \\
\hline $\mathrm{Eu} / \mathrm{Eu}^{*}$ & 1.42 & 0.84 & 0.78 & 0.95 & 0.85 & 0.93 & 1.06 & 0.92 & 0.83 & 0.90 & 0.91 & 0.76 & 0.84 & 0.95 \\
\hline $\mathrm{La}_{\mathrm{N}} / \mathrm{Yb}_{\mathrm{N}}$ & 2.62 & 2.58 & 3.63 & 4.09 & 4.66 & 3.12 & 2.51 & 2.79 & 4.27 & 4.45 & 2.71 & 2.58 & 2.77 & 2.94 \\
\hline$\Sigma$ REE & 28.67 & 122.50 & 113.72 & 139.15 & 115.01 & 108.93 & 62.50 & 76.82 & 149.64 & 134.69 & 96.86 & 108.90 & 94.10 & 86.76 \\
\hline
\end{tabular}


( $\mathrm{K}_{\alpha} \mathrm{X}$-ray lines): diopside ( $\left.\mathrm{Si}, \mathrm{Ca}\right)$, kyanite ( $\left.\mathrm{Al}\right)$, fayalite $(\mathrm{Fe})$, rutile $(\mathrm{Ti})$, pyrope $(\mathrm{Mg})$, spessartine $(\mathrm{Mn})$, albite $(\mathrm{Na})$, orthoclase $(\mathrm{K})$, fluorapatite $(\mathrm{P}, \mathrm{F})$ and gahnite $(\mathrm{Zn})$. The crystallochemical formulae of pyroxene were calculated on the basis of 6 oxygens, $8 \mathrm{O}$ for feldspar and $22 \mathrm{O}$ for micas. Amphibole formulae were obtained assuming $23 \mathrm{O}$ and two ions of $\mathrm{OH}, \mathrm{F}$ and $\mathrm{Cl}$; ferric iron contents were estimated using the recalculation method 13 eCNK (Leake et al. 1997). The abbreviations of mineral names are those of Kretz (1983).

Whole-rock powders were analysed in the Acme Analytical Laboratories, Vancouver, Canada (Tab. 2). Major-element contents were determined using ICP$\mathrm{ES}$ after fusion with $\mathrm{LiBO}_{2}$. Concentrations of $\mathrm{C}$ and $\mathrm{S}$ were measured by LECO analysis and loss on ignition (LOI) was determined from weight-loss after ignition at $1000^{\circ} \mathrm{C}$. Rare earth elements and majority of trace elements were measured by ICP-MS following fusion with $\mathrm{LiBO}_{2}$. Base-metal $(\mathrm{Cu}, \mathrm{Pb}$ and $\mathrm{Zn})$ concentrations were obtained by ICP-MS analyses after dissolving the sample in aqua regia. The whole-rock analytical data were plotted and interpreted using GCDkit software (Janoušek et al. 2006).

\section{Lithology of Santa Lucía Volcano}

The main lithologic divisions of Santa Lucía Volcano were established based on stratigraphy, petrology, and field relations (Fig. 1c). Volcanic rocks, which belong to different parts of the Santa Lucía Volcano, have been previously radiometrically dated, yielding ages of 17 to $25 \mathrm{Ma}$. The youngest ages were those for basalt collected near village of Santa Lucía (17.1 $\pm 0.9 \mathrm{Ma}: \mathrm{K}-\mathrm{Ar}$, Ehrenborg 1996) and near Boaco (17.61 $\pm 0.27 \mathrm{Ma}$ : Ar-Ar, Elming et al. 2001). The oldest age of $24.5 \pm 0.8 \mathrm{Ma}$ corresponds to a whole-rock basalt sample from the vicinity of Boaco (K-Ar: Elming et al. 1999).

Santa Lucía Volcano is approximately $15 \mathrm{~km}$ wide at its base, and is characterized by a large volume of pyroclastic rocks and andesitic lava flows. Lithological units represent periodical eruptions of chemically similar magma. Six lithological units of volcanic rocks have been recognized in the whole volcanic complex, as follows:

\subsection{Unit I: Boaco-type Ignimbrite}

Grey-green or grey-brown, massive, non-welded ignimbrites (Tab. 1) are rhyolitic to trachyandesitic in composition (Fig. 2a). Usually they are characterized by reverse grading with upward enrichment of pumice clasts. Pyroclastic surge and ash-fall deposits as well as epiclastics including debris flow deposits accompany them in the lower part. The surge deposits consist of volcanic ash, pumice and rare small lithic fragments. Cross bedding is common. All members of this unit are strongly altered (mainly zeolitized and chloritized).

The fine-grained matrix consists of subangular to angular fragments of crystals, glass shards and small vesicular glassy lapilli. Angular glass-shards are partly replaced by palagonite, zeolites (heulandite; $\mathrm{Si} / \mathrm{Al}=$ $4.3-4.6, \mathrm{Ca} /(\mathrm{K}+\mathrm{Na})=4-5)$ and quartz. Relicts of primary glass have rhyolitic chemical composition $\left(\mathrm{SiO}_{2}=\right.$ 69 wt. $\%, \mathrm{~K}_{2} \mathrm{O}+\mathrm{Na}_{2} \mathrm{O}=0.6$ wt. \%). Crystal fragments are represented by quartz, $\mathrm{K}$-feldspar $\left(\mathrm{Or}_{100}\right)$, amphiboles (magnesiohornblende; $\mathrm{Mg} /(\mathrm{Mg}+\mathrm{Fe})=0.74-0.77, \mathrm{Si}=$ 6.96-7.17 apfu), clinopyroxenes (Tab. 3; augite; $\mathrm{Mg} /$ $(\mathrm{Fe}+\mathrm{Mg})=0.71-0.77, \mathrm{Ca}=0.77-0.81 \mathrm{apfu})$ and partly sericitized and/or zeolitized plagioclase $\left(\mathrm{An}_{38-43}\right)$.

Several $\mathrm{cm}$ - to dm-thick lithic-rich layers are locally present. They contain abundant angular to subangular rock fragments (Fig. 2b) and pumice up to $5 \mathrm{~cm}$ in diameter. Juvenile fragments consist of non-vesiculated angular rhyolite to dacite. These have fluidal texture and phenocrysts of plagioclase $\left(\mathrm{An}_{48-49}\right)$ with $\mathrm{K}$-feldspar $\left(\mathrm{Or}_{94} \mathrm{Ab}_{6}\right)$ enclosed in glassy matrix. Non-vesiculated to poorly vesiculated altered andesitic lithics are a minor constituents (10 vol. \%).

\subsection{Unit II: Fonseca-type Ignimbrite and dacitic-rhyolitic lavas}

The Unit II consists of several intensively welded ignimbrite layers (several $\mathrm{m}$ thick) alternating with weakly welded facies (Fig. 2c), fall-out deposits and epiclastic rocks. Welded, usually eutaxitic or lithic-rich ignimbrites are grey to red, with abundant fiamme and lithic fragments. Angular to subangular lithics up to $30 \mathrm{~cm}$ in diameter are often aphanitic or glassy porphyritic rhyolite and andesite. Fine-grained, non-welded to slightly welded ignimbrites are usually rhyodacitic to rhyolitic in composition. They locally contain layers with abundant feldspar and pumice fragments (usually several $\mathrm{mm}$ to $\mathrm{cm}$ in diameter - Fig. 2c). The fine-grained matrix (over $60 \mathrm{vol} . \%$ on average) contain c. $37 \mathrm{vol} . \%$ of plagioclase $\left(\mathrm{An}_{35-37}\right)$ and 0.5 vol. \% of $\mathrm{Fe}-\mathrm{Ti}$ oxides, mainly hematite and ilmenite $(\mathrm{Fe} /(\mathrm{Fe}+\mathrm{Mg}+\mathrm{Mn})=0.93)$. The glassshards in matrix are partly recrystallized in an assemblage of alkali feldspar $\left(\mathrm{Or}_{71-78} \mathrm{Ab}_{20-26}\right)$, quartz and zeolites (heulandite and yugawaralite). Rare co-ignimbrite ashfall deposits are also present, consisting of white layers up to $2 \mathrm{~m}$ thick, locally with accretionary lapilli (Fig. 2d). A photomicrograph of the poorly sorted Fonseca-type ignimbrite is shown in Fig. 2e. Glass shards, pumice fragments and xenocrysts are main constituents of the ignimbrite. The Y-shaped and cuspate shards fragmented by nucleation, growth and disruption of vesicles during magmatic explosive eruption reveal axiolitic internal tex- 

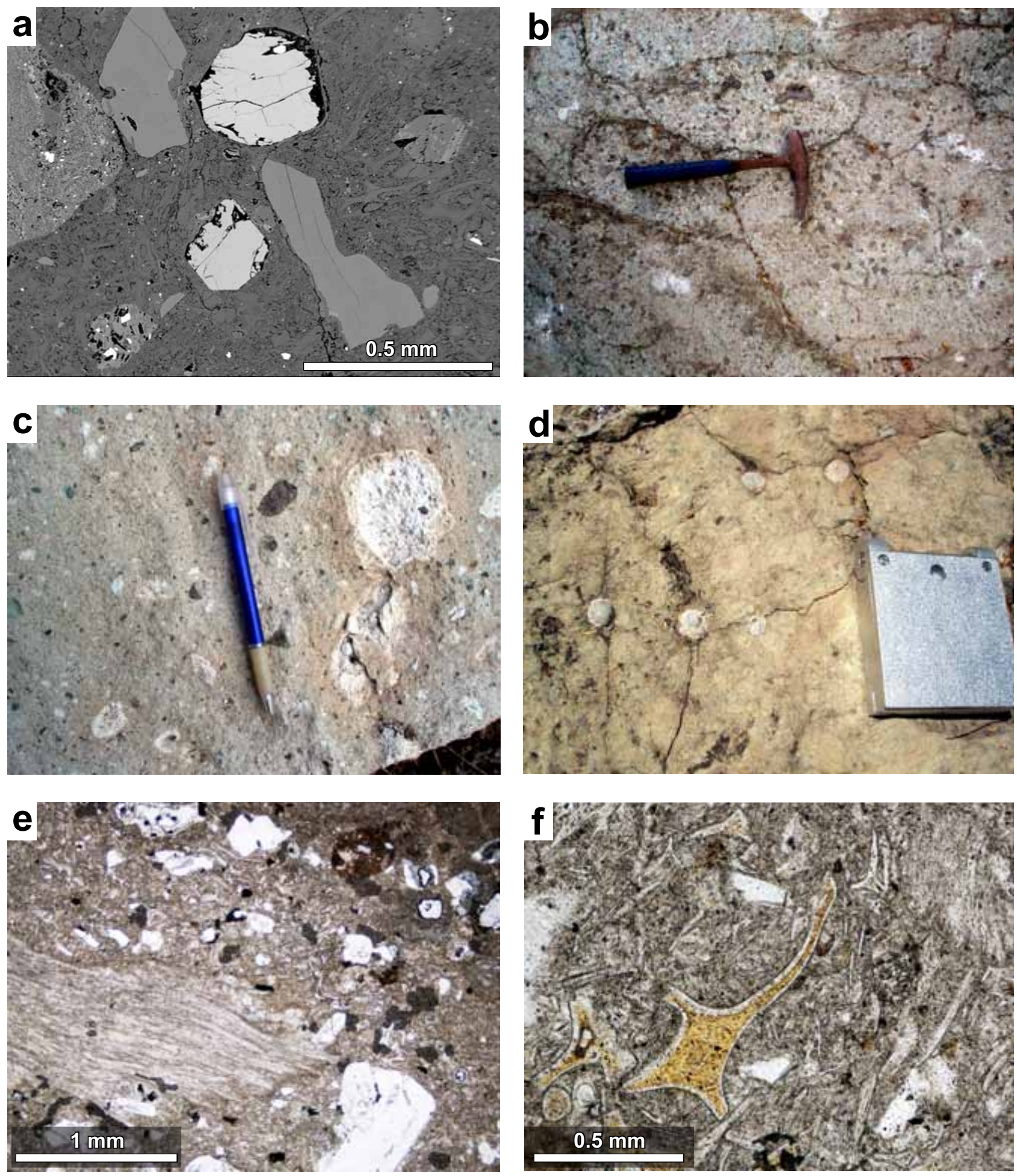

Fig. 2 Typical textures of ignimbrites from units I and II: a - Ignimbrite of Boaco type (sample D273, BSE photo); b - Outcrop of ignimbrite of Boaco type (sample D0273); c - Fonseca-type ignimbrite with large amount of pumice fragments (sample D0134); d - Ash-fall deposits with accretionary lapilli (sample H123); e - The poorly-sorted texture formed by glass shards, pumice fragments and xenocrysts; the Y-shaped and cuspate shards reveal the axiolitic internal texture (sample E148); f - Shards filled up by minute heulandite crystals (sample E149). 
Tab. 3 Representative chemical compositions of amphibole and pyroxene in the volcanic rocks (wt. $\%$ and apfu based on $23 \mathrm{O}$ and $6 \mathrm{O}$, respectively)

\begin{tabular}{|c|c|c|c|c|c|c|c|}
\hline \multirow[b]{2}{*}{ Sample } & \multicolumn{2}{|c|}{ Amphibole } & \multicolumn{5}{|c|}{ Pyroxene } \\
\hline & D273 & D273 & D273 & D204 & D136 & D136 & D275 \\
\hline Unit & I & I & I & III & V & $\mathrm{V}$ & $\mathrm{V}$ \\
\hline $\mathrm{SiO}_{2}$ & 48.78 & 49.12 & 52.31 & 52.19 & 51.33 & 50.82 & 48.97 \\
\hline $\mathrm{TiO}_{2}$ & 1.52 & 1.19 & 0.40 & 0.61 & 0.74 & 0.36 & 0.98 \\
\hline $\mathrm{Al}_{2} \mathrm{O}_{3}$ & 6.45 & 5.39 & 1.67 & 1.77 & 1.50 & 0.47 & 3.81 \\
\hline $\mathrm{Cr}_{2} \mathrm{O}_{3}$ & 0.01 & 0.00 & 0.01 & 0.02 & 0.01 & 0.00 & 0.03 \\
\hline $\mathrm{FeO}^{\prime}$ & 9.44 & 9.39 & 6.75 & 10.86 & 10.31 & 21.63 & 5.42 \\
\hline $\mathrm{Fe}_{2} \mathrm{O}_{3}{ }^{\prime}$ & 3.60 & 3.44 & 1.98 & 0.96 & 1.97 & 3.47 & 5.20 \\
\hline $\mathrm{MnO}$ & 0.58 & 0.72 & 0.47 & 0.40 & 0.42 & 0.88 & 0.51 \\
\hline $\mathrm{MgO}$ & 15.15 & 15.69 & 15.94 & 15.69 & 14.59 & 18.61 & 14.37 \\
\hline $\mathrm{CaO}$ & 11.46 & 10.94 & 20.14 & 17.43 & 18.43 & 3.85 & 20.67 \\
\hline $\mathrm{Na}_{2} \mathrm{O}$ & 1.29 & 1.19 & 0.31 & 0.29 & 0.35 & 0.10 & 0.30 \\
\hline $\mathrm{K}_{2} \mathrm{O}$ & 0.41 & 0.28 & 0.02 & 0.01 & 0.02 & 0.00 & 0.01 \\
\hline $\mathrm{H}_{2} \mathrm{O}$ & 2.10 & 2.08 & - & - & - & - & - \\
\hline $\mathrm{Cl}$ & 0.10 & 0.07 & - & - & - & - & - \\
\hline $\mathrm{O}=2 \mathrm{Cl}$ & -0.02 & -0.02 & - & - & - & - & - \\
\hline Total & 100.87 & 99.47 & 99.97 & 100.23 & 99.66 & 100.18 & 100.25 \\
\hline $\mathrm{Si}$ & 7.009 & 7.136 & 1.936 & 1.942 & 1.931 & 1.933 & 1.827 \\
\hline $\mathrm{Al}$ & 1.092 & 0.923 & 0.073 & 0.078 & 0.066 & 0.021 & 0.168 \\
\hline $\mathrm{Fe}^{3+}$ & 0.389 & 0.375 & 0.055 & 0.027 & 0.056 & 0.099 & 0.146 \\
\hline $\mathrm{Cr}$ & 0.001 & 0.000 & 0.000 & 0.000 & 0.000 & 0.000 & 0.001 \\
\hline $\mathrm{Ti}$ & 0.164 & 0.130 & 0.011 & 0.017 & 0.021 & 0.010 & 0.027 \\
\hline $\mathrm{Fe}^{2+}$ & 1.134 & 1.140 & 0.209 & 0.338 & 0.324 & 0.688 & 0.169 \\
\hline $\mathrm{Mn}$ & 0.071 & 0.088 & 0.015 & 0.013 & 0.013 & 0.028 & 0.016 \\
\hline $\mathrm{Mg}$ & 3.244 & 3.398 & 0.879 & 0.870 & 0.819 & 1.056 & 0.799 \\
\hline $\mathrm{Ca}$ & 1.764 & 1.702 & 0.799 & 0.695 & 0.743 & 0.157 & 0.826 \\
\hline $\mathrm{Na}$ & 0.358 & 0.335 & 0.022 & 0.021 & 0.026 & 0.007 & 0.022 \\
\hline K & 0.076 & 0.052 & 0.001 & 0.001 & 0.001 & 0.000 & 0.000 \\
\hline $\mathrm{Cl}$ & 0.023 & 0.017 & - & - & - & - & - \\
\hline Total & 15.302 & 15.280 & 4.000 & 4.000 & 4.000 & 4.000 & 4.000 \\
\hline
\end{tabular}

ture formed during the devitrification phase. Shard rims are built by microquartz, and well visible axial canals confirm the vitroclastic nature of the matrix. Devitrified glass is the main component of clear margins, while brown centre is formed by radially grown minute crystals of heulandite (Fig. 2f) or K-feldspar. Axiolitic nature is accentuated by cuspate shards with brown recrystallized centres, and margins of very fine ash converted into a mixture of fine quartz and phyllosilicates. Other randomly orientated components are crystal fragments (feldspar, plagioclase, quartz and biotite) and pumice. Matrix is usually composed of a fine aggregate of minerals including those from vapour-phase crystallization. Lapilli of tabular pumice are elongated, aligned parallel to the deposit as a result of preferred orientation of tabular particles in laminar flow. These processes affected also some of the crystals (feldspar). Shards are surrounded by micropoikilitic matrix with shard relics and fragments of feldspar crystals. Modified texture is found in welded ignimbrites from the San Lorenzo and Las Lajas calderas, with strongly deformed shards (Fig. 3a).

Dacites to rhyolites form small dykes and lava flows. Porphyritic to aphanitic dacites to rhyolites, sometimes with fluidal textures, consist of oscillatory-zoned plagioclase $\left(\mathrm{An}_{35-41} \mathrm{Or}_{1-2}\right)$, K-feldspar/sanidine $\left(\mathrm{Ab}_{53-71} \mathrm{Or}_{20-43}\right)$, quartz, clinopyroxene, titanomagnetite and ilmenite. In places, these rocks are strongly hydrothermally altered.

\subsection{Unit III: "Lower andesite" lava flows}

This unit is defined as deeply altered sets of basaltic andesite lavas with clinker facies on top. In the upper part of the unit, dacites to andesites occur in form of up to $2 \mathrm{~m}$ thick lavas. The majority of rocks in the Unit III are porous, and therefore prone to strong alteration and weathering. Chemical weathering and hydrothermal alteration (e.g. chloritization, carbonization or argillization) transform primary minerals and glass into a mixture of 

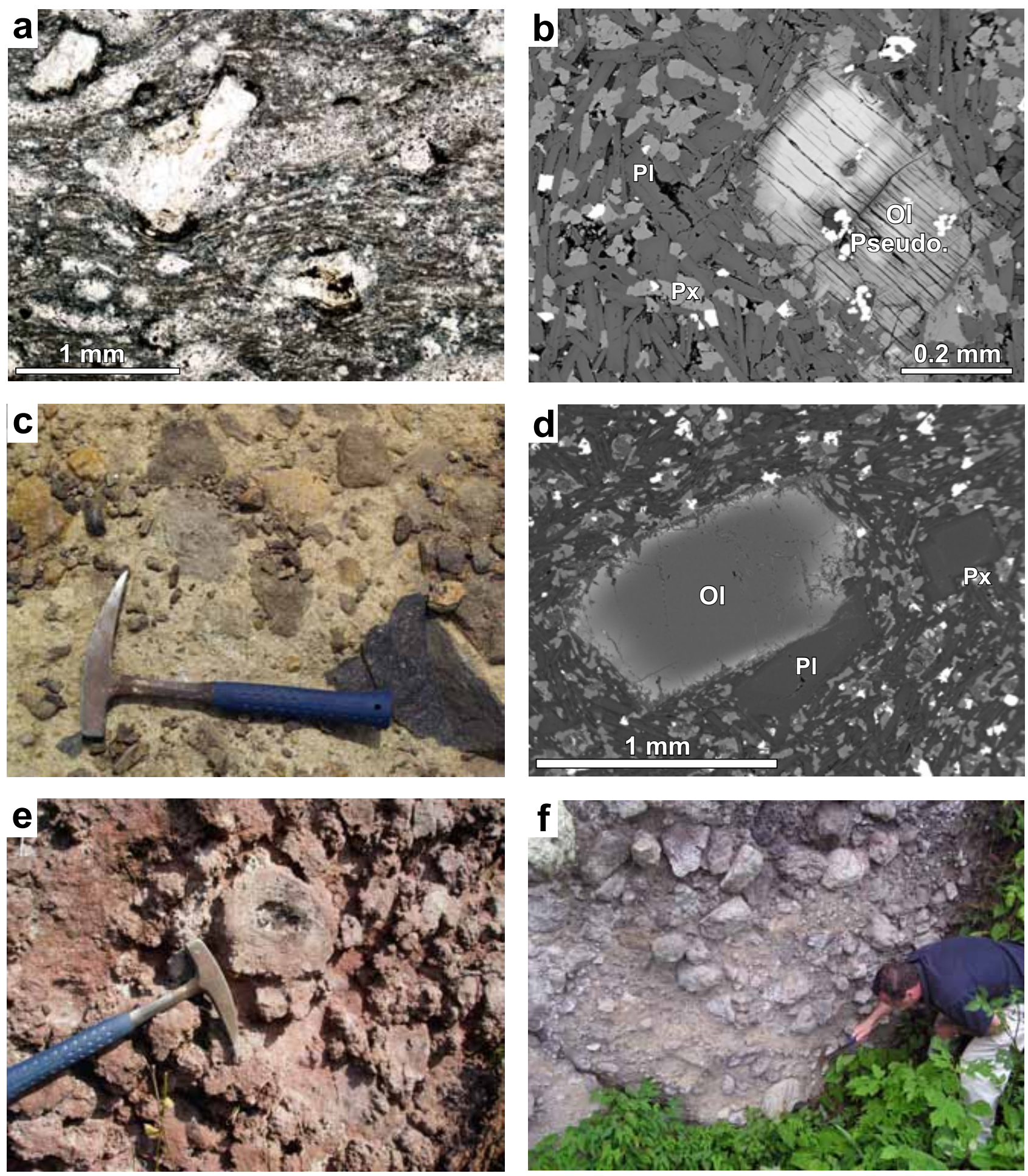

Fig. 3 Typical textures of rocks from units II-VI: a - Ignimbrite with densely deformed shards showing strong compaction, stretching and moulding of elongated shards against the feldspar crystals due to plastic deformation under fairly hot emplacement conditions, axiolitic devitrification can be also recognized (sample H153, San Lorenzo Volcano); $\mathbf{b}$ - Altered basalt from Unit III with iddingsite pseudomorph after olivine (BSE photo, sample D0204); c - Non-welded agglomerate from Unit IV west of Santa Lucía village (sample H0038); d - Olivine basalt from upper part of Unit V, Santa Lucía (BSE photo); e - Scoria fall deposit, upper part of Unit V, southeast of Boaco (sample D0145); f - Block-supported lahar deposits, SE slope of the Santa Lucía Volcano, Cerro San Francisco (D0056). 
limonite, chlorites, quartz and clay minerals and make the rock weak and easily deformable. Pyroclastic deposits are rare, being formed by up to $3 \mathrm{~m}$ thick layers alternating with massive basaltic lavas. Stratified pyroclastic fall deposit consists of well-sorted scoria and lapilli beds. Basaltic andesites in fresh state are dark grey to reddish, fine- to medium-grained porphyritic rocks. The groundmass of lavas is fine-grained, ophitic to subtrachytic. Some clinopyroxene phenocrysts are poikilitic, enclosing plagioclase laths. Augite (Tab. $3, \mathrm{Mg} /(\mathrm{Fe}+$ $\mathrm{Mg})=0.70-0.73, \mathrm{Ca}=0.70-0.77 \mathrm{apfu})$ predominates in the groundmass, whereas pigeonite $(\mathrm{Mg} /(\mathrm{Fe}+\mathrm{Mg})=$ $0.66, \mathrm{Ca}=0.15 \mathrm{apfu}$ ) is a minor groundmass phase. The discontinuously zoned plagioclase is mostly labradorite $\left(\mathrm{An}_{70}\right)$, and only narrow rims of the plagioclase laths correspond to andesine $\left(\mathrm{An}_{45-46}\right)$. Iddingsite pseudomorphs after olivine are also present (Fig. 3b). Hematite and Ti-magnetite are typical accessory phases; chromite occurs only occasionally. Magnetite is often partially maghemitized. Minerals of the serpentinite group, clay minerals and chlorite are secondary constituents.

Vesiculated to massive dacites and andesites contain phenocrysts of plagioclase and/or amphibole. The groundmass consists of glass (partly or completely altered) and equigranular grains of plagioclase and rare quartz.

\subsection{Unit IV: So-called "agglomerates"}

The fourth unit is represented mainly by lithic-rich pyroclastic flow deposits, which were originally named "agglomerates of the Coyol Group" by Garayar (1972). The total thickness reaches up to 250 meters. This unit is characterized by several meters-thick layers of mainly non-welded matrix-supported chaotic deposit consisting of large fragments of angular to subangular black scoriae and non-vesiculated lava fragments (up to $30 \mathrm{~cm}$ ) randomly distributed in a weathered ash matrix (Fig. 3c). These accumulations could be interpreted as block-andash flow deposits.

The juvenile black and light grey andesitic to basaltic scoria fragments exhibit an aphanitic-porphyritic texture with phenocrysts of plagioclase and pyroxene. The proportion of vesicles ranges from 10 up to 55 vol. \%. Non-welded pyroclastic flow deposits are locally intercalated with volcaniclastic debrites. Thickness of these deposits varies from several $\mathrm{dm}$ to few meters. The deposits represent pyroclastic material reworked by fluvial transport. The discrimination between block-andash deposits and their resedimented deposits is rather difficult because both types are weakly cemented and both transport processes resulted in similar shapes of magmatic clasts.

\subsection{Unit V: "Upper andesite" lava flows}

Two main petrographic groups were recognized in this unit. The lower part consists predominantly of amphibole- or pyroxene-rich andesites to dacites with scarce rhyolites. The upper part is built by olivine- and pyroxene-rich basalts (Fig. 3d), being dominant on plateaus in the northern part of the Santa Lucía caldera. The total thickness of the Unit V reaches $70 \mathrm{~m}$. Lateritic weathering of the rocks is common. Dykes and rare pyroclastic deposits accompany the lava flows.

Individual massive lava flows are predominantly of aa type and 2 to $10 \mathrm{~m}$ thick. A typical example of the upper part of this unit is massive, poorly vesiculated olivine basalt. Clinopyroxene microlites correspond to augite and pigeonite (Morimoto 1988). Augite cores (Mg/ $(\mathrm{Fe}+\mathrm{Mg})=0.68-0.70, \mathrm{Ca}=0.74-0.80 \mathrm{apfu})$ are often rimmed by thin pigeonite rims $(\mathrm{Mg} /(\mathrm{Fe}+\mathrm{Mg})=0.56, \mathrm{Ca}$ $=0.16 \mathrm{apfu}$ ). Olivine $\left(\mathrm{Fo}_{49-81}\right)$ phenocrysts (up to $1 \mathrm{~mm}$ ) and microlites are normally zoned with $\mathrm{X}_{\mathrm{Fe}}$ increasing towards the rim (Fig. 3d). Plagioclase is predominantly present as microlites in the groundmass but sometimes also as phenocrysts up to $1.5 \mathrm{~mm}$ in size. The normally zoned groundmass plagioclase laths could be classified as oligoclase to labradorite $\left(\mathrm{An}_{26-62}\right)$. The oscillatory-zoned plagioclase phenocrysts $\left(\mathrm{An}_{71-91}\right)$ are anorthite-bytownite in the central part and labradorite on the rim. They usually contain small oval inclusions of clinopyroxene or altered glass. Glass in the groundmass is replaced by chlorite and clay minerals. Ilmenite and magnetite are typical accessory minerals.

Coarse-grained ill-sorted clast-supported non-welded basaltic andesite scoriae facies is present only locally, in 1-5 $\mathrm{m}$ thick layers (Fig. 3e). According to the grain-size and texture, these could represent remnants of scoria cones, from which the lavas may have been emitted.

\subsection{Unit VI: Lahar deposits}

Coarse-grained lithic-rich deposits dominate the uppermost parts along the rims of the Santa Lucía caldera, forming imposing cliffs around the depression. This unit represents the youngest preserved deposit in the area. The ill-sorted deposits consist of flow units with thickness ranging from 1 to $10 \mathrm{~m}$. Normally, they are not stratified, although reverse grading of large lithic clasts can be observed in some sections. Deposits are matrix- to clast-supported (Fig. 3f) and contain angular to subangular dacite and basaltic andesite clasts up to 2 $\mathrm{m}$ in diameter (occasionally up to $5 \mathrm{~m}$ ). Their texture is typically porphyritic with phenocrysts of pyroxene and feldspar. Matrix is usually cemented. Volcaniclastic sandstones and siltstones occur in layers up to $2.0 \mathrm{~m}$ thick. 

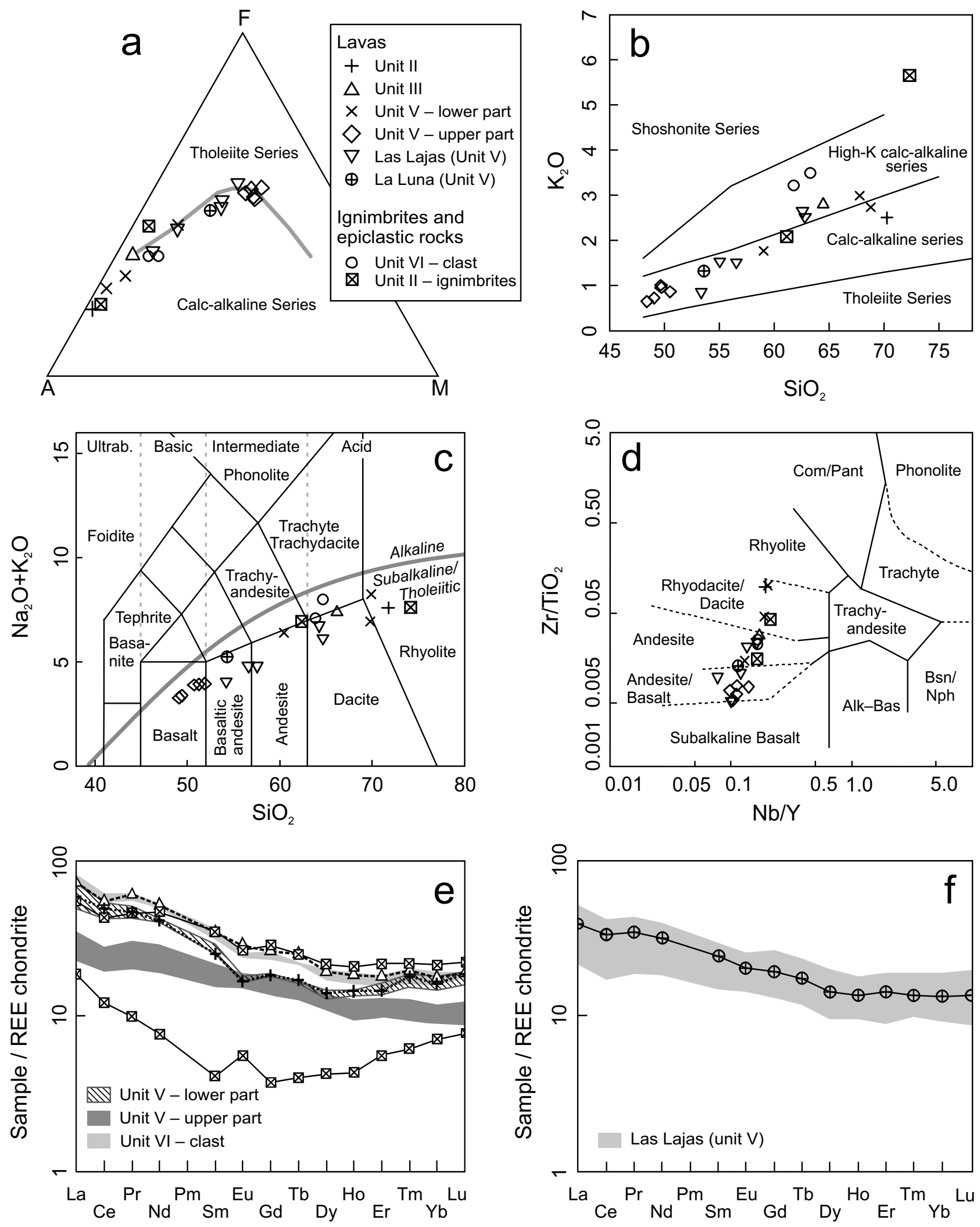

Fig. 4 Classification diagrams for volcanic rocks and ignimbrites: a - Ternary plot AFM $\left(\left(\mathrm{Na}_{2} \mathrm{O}+\mathrm{K}_{2} \mathrm{O}\right)-\mathrm{FeO}_{1}-\mathrm{MgO}\right.$, Irvine and Baragar 1971);

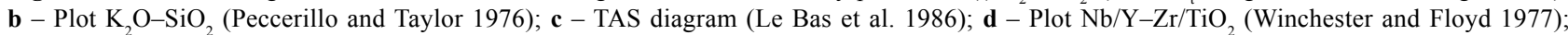
e-f - Chondrite-normalized REE patterns (normalization after Boynton 1984) for rocks from the Santa Lucía Volcano (e), La Luna and Las Lajas volcanoes (f). Chemical composition of volcanic rocks corresponds to the Santa Lucía (1-6), Las Lajas (7) and La Luna (8) volcanoes. 
Clasts of varying composition, shape and roundness were already transported by lahars. A very interesting aspect of the composition and depositional textures of lahar deposits from the two localities (Santa Lucía and Las Lajas) is their striking similarity.

\section{Whole-rock geochemistry}

Volcanic rocks of the Santa Lucía area show a wide range of compositions (Tab. 2). Chemistry of most of the studied rocks has been significantly modified by considerable alteration. The degree of alteration can be assessed by the loss on ignition (LOI) values $(0.5-16.2$ wt. \%). Moreover, all samples show petrographic evidence of at least weak alteration, such as the presence of newly formed chlorite, serpentine minerals, iddingsite, zeolite and sericite. For the purpose of determining the primary unaltered geochemical character, samples with $>3$ wt. \% LOI were excluded from interpretations. This is the case, in particular, of samples from the units I and IV which are always strongly altered (zeolitization and chloritization).

The AFM diagram (Irvine and Baragar 1971; Fig. 4a) characterizes the majority of the samples as calc-alkaline. In the $\mathrm{SiO}_{2}-\mathrm{K}_{2} \mathrm{O}$ plot (Peccerillo and Taylor 1976; Fig. $4 b$ ), most rocks (13 samples) seem to belong to the normal calc-alkaline series straddling the boundary of the adjacent high-K calc-alkaline domain at higher $\mathrm{SiO}_{2}$ contents. The $\mathrm{K}_{2} \mathrm{O} / \mathrm{Na}_{2} \mathrm{O}$ ratios are usually low $(0.1-0.6)$.

\subsection{Unit II}

Two relatively fresh samples of ignimbrites (H143 and H256) and one lava (D045) were analysed and plotted in the TAS diagram (Le Bas et al. 1986; Fig. 4c). They correspond to subalkaline rhyolite and trachyandesite. In the $\mathrm{Zr} / \mathrm{TiO}_{2}$ versus $\mathrm{Nb} / \mathrm{Y}$ diagram (Winchester and Floyd 1977; Fig. 4d), the ignimbrites are classified as andesite or rhyodacite, and the rock from the lava flow corresponds to dacite. Chondrite-normalized REE patterns from the ignimbrites are dissimilar (Fig. 4e), with differences in total REE contents (29 and $123 \mathrm{ppm}$ ). Generally, acid ignimbrite with lithic fragments (andesite and basalt) cannot provide reliable chemical data. Rhyolite and one unaltered ignimbrites (without large lithic fragments) show a similar REE distribution trend, characterized by a gentle slope from LREE to HREE $\left(\mathrm{La}_{\mathrm{N}} / \mathrm{Yb}_{\mathrm{N}}=2.6-3.6\right)$.

\subsection{Units III and V}

According to TAS classification (Fig. 4c), a sample of fresh massive lava rock from Unit III (H035) corresponds

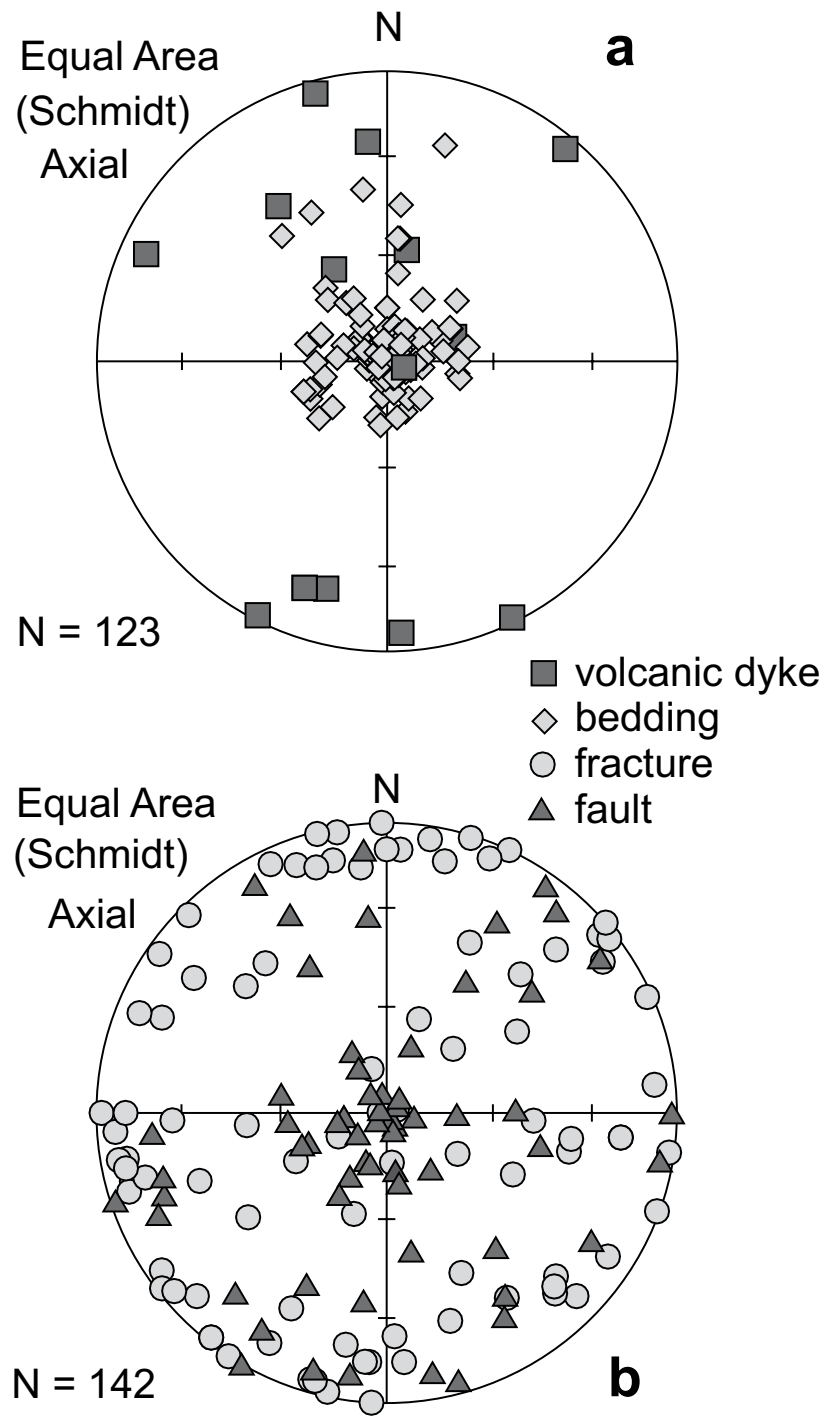

Fig. 5 Lower-hemisphere equal-area projection showing the orientation of the (a) bedding and basalt dykes and sills from Unit V, fractures and faults, all in the Santa Lucía Volcano area (b).

to dacite, whereas in the $\mathrm{Zr} / \mathrm{TiO}$, versus $\mathrm{Nb} / \mathrm{Y}$ diagram it is classified as andesite (Fig. 4d).

Rocks from the Unit $\mathrm{V}$ show a bimodal composition in the TAS diagram (Fig. 4c). Samples from its lower part correspond to subalkaline rhyolite, dacite and andesite, whereas those from the upper part can be classified as basalt and basaltic andesite. A similar bimodal distribution of samples is seen in the $\mathrm{Zr} / \mathrm{TiO}_{2}$ versus $\mathrm{Nb} / \mathrm{Y}$ diagram (Fig. 4d).

The REE distribution patterns for lavas from Unit II and lower part of the Unit V are comparable. Typical of both units is a fair degree of LREE fractionation $\left(\mathrm{La}_{\mathrm{N}} /\right.$ $\mathrm{Yb}_{\mathrm{N}}=3.1-4.6$; Tab. 2), with a weak negative Eu anomaly $\left(\mathrm{Eu} / \mathrm{Eu}^{*}=0.78-0.93\right)$. The uniform REE abundances $\left(\sum \mathrm{REE}=53-77 \mathrm{ppm}\right)$ and distribution patterns $\left(\mathrm{La}_{\mathrm{N}} /\right.$ $\left.\mathrm{Yb}_{\mathrm{N}}=2.5-3.5\right)$, particularly the absence of Eu anomaly 
$\left(\mathrm{Eu} / \mathrm{Eu}^{*}=0.9-1.1\right.$, Fig. $\left.4 \mathrm{e}\right)$ are characteristic features of the basalts from upper part of the Unit V.

\subsection{Unit VI}

Two volcanic clasts from the epiclastic unit correspond to subalkaline trachydacite and dacite in the TAS classification (Fig. 4c); however, in the $\mathrm{Zr} / \mathrm{TiO}_{2}$ versus $\mathrm{Nb} / \mathrm{Y}$ diagram both samples correspond to andesite (Fig. 4d). Chondrite-normalized REE patterns of the same rocks show a gently decreasing trend from LREE to HREE $\left(\mathrm{La}_{\mathrm{N}} / \mathrm{Yb}_{\mathrm{N}}=4.3-4.5\right)$ and a weak negative $\mathrm{Eu}$ anomaly $\left(\mathrm{Eu} / \mathrm{Eu}^{*}=0.83-0.90\right)$. The REE distribution patterns of both volcanic clasts are similar to dacite from the Unit III. Patterns are sub-parallel, with differences in the total REE contents (135-150 ppm). From petrographic and geochemical points of view, volcanic clasts from epiclastic sediments are comparable with lavas of the neighbouring volcanoes (Las Lajas and La Luna).

\subsection{Volcanic rocks from Las Lajas and La Luna volcanoes}

Las Lajas volcanic rocks show a bimodal composition: dacite and andesite to basaltic andesite. The sole sample from the La Luna Volcano is classified as basaltic andesite (TAS diagram, Fig. 4c). The REE distribution patterns of the dacites from the Unit $\mathrm{V}$ on Las Lajas Volcano (Fig. 4f) are similar to dacites and rhyolites from the Unit V on Santa Lucía, except for the slightly lower LREE contents and absence of Eu anomaly in the former. The majority of rocks from Las Lajas show higher Ba contents (757-1616 ppm) compared to similar rocks (201-1041 ppm) from the surrounding volcanoes.

\section{Structural characteristics of the Santa Lucía Volcano}

Structural features in the Santa Lucía volcanic complex include subhorizontal bedding of tuff layers, ignimbrites and lavas. Such features are mostly developed within the units I, II, IV and VI. Approximately $95 \%$ of measurements of bedding dips are less than $30^{\circ}$ (Fig. 5a). Bedding surfaces dipping at $40^{\circ}$ and $66^{\circ}$ to the $\mathrm{S}$ to $\mathrm{SE}$ are exclusively localized in the southern part of Santa Lucía stratoshield, affected by a giant rockslide reported by Baroň et al. (2008). Therefore, these values should not reflect the primary deposition.

Orientation of the fracture planes is randomly distributed in the diagram in Fig. $5 \mathrm{~b}$ with maxima to the $\mathrm{E}-\mathrm{W}$, $\mathrm{S}-\mathrm{N}$ and NW-SE, and dip at $80-90^{\circ}$.
The dominant strikes of the basalt dyke are NE-SW or NW-SE with prevailing subvertical dips. This is consistent with the orientation of two main fault systems found in the area of Santa Lucía Volcano (Fig. 1b). The dominant movement on the NE-SW-striking faults is a dextral strike-slip with a considerable dip-slip component. The SE-NW-striking strike-slip faults are sinistral, but sometimes overprinted by younger normal movements. The older tectonic faults are represented by indistinct $\mathrm{N}-$ S-oriented normal faults, which were re-activated during the formation of the SE-NW-striking faults. A system of distinct normal faults has been described from the vicinity of the Santa Lucía Volcano (Baroň et al. 2008) and can be interpreted as a result of subsidence in the central part of the Santa Lucía caldera. Younger low-angle faults are related to a giant rockslide (Baroň et al. 2008) in the southern part of the volcano. The area of the rockslide is characterized by frequent occurrence of low-angle normal faults formed by gravitational collapse. These are present mainly in the accumulation zone of the rockslide, and affected predominantly strongly altered rocks (mainly ignimbrites).

\section{Discussion}

\subsection{Correlation with the neighbouring Tertiary volcanic centres}

The neighbouring volcanic centres to the Santa Lucía Volcano are La Luna to the north, San Lorenzo to the south (Fig. 1b) and Las Lajas to the west. Based on petrological and geochemical aspects, some lithological units of the Santa Lucía Volcano can be correlated with those of the surrounding Tertiary volcanoes. The lithology of the San Lorenzo Volcano is very similar to that of Santa Lucía, and all units defined here can be also distinguished in San Lorenzo (Fig. 1).

\subsubsection{La Luna}

The horseshoe-shaped edifice of the La Luna Volcano includes three calderas and consists mainly of sequence of basalt to basaltic andesite lavas alternating with pyroclastic scoria deposits (lithic-rich facies with subangular fragments of basalt and andesite lavas). This sequence of lava flows and pyroclastic facies is petrologically and geochemically very similar to the units IV and V of the Santa Lucía Volcano. High elevations in the central part of the caldera are built by basalts and hydrothermally altered rocks, perhaps dacites. Strongly altered rocks consist of secondary quartz, clay minerals (mainly pyrophyllite), K-feldspar and relics of plagioclase. 


\subsubsection{Las Lajas}

The Las Lajas Volcano represents the best-preserved caldera topography in the study area. The Las Lajas was considered to be of Holocene age based on its wellpreserved morphology (McBirney and Williams 1965); however, radiometric dating of $9.48 \pm 0.03 \mathrm{Ma}(\mathrm{Ar}-\mathrm{Ar}$, Saginor 2008) indicates a Late Miocene age. Although the volcanic edifice was probably formed during the Miocene but the last explosive eruption might be of Quaternary age.

The Las Lajas caldera consists predominantly of basaltic to basaltic andesite lavas, locally showing minor pyroclastic layers in the upper part, and with up to $180 \mathrm{~m}$ thick accumulations of debris-flow deposits (lahars). These epiclastic rocks are similar to those from Unit VI in the Santa Lucía sequence. Five dacitic lava domes are located inside the caldera.

Ignimbrites were produced at the final explosive period of the Las Lajas Volcano. The matrix is rich in crystals and densely deformed glass shards. Feldspar dominates among the crystals. Amphibole crystals are overgrown by younger plagioclase grains. The ignimbrites show effects of strong compaction, stretching and moulding of elongated shards around the plagioclase and K-feldspar crystals due to plastic deformation at "hot-glass" temperature during emplacement. Axiolitic devitrification can be also recognized. Welding and compaction often affect pumice fragments.

\subsection{Evolution of the Santa Lucía volcanic structure}

The eruptive sequence of the Santa Lucía Volcano is characterized by an alternation of effusive and explosive activity. The Santa Lucía Volcano started to grow on the relatively flat (peneplaned) surface, formed by partly altered and weathered ignimbrites belonging to the Unit I. In respect to magma composition and the eruptive style, five stages of evolution can be distinguished:

(1) The construction of a composite cone started during the first stage, alternating the silicic ignimbriteforming eruptions (Unit II) with effusive activity (Unit III). Basaltic lava flow from Unit III yielded a $\mathrm{K}-\mathrm{Ar}$ age of $24.5 \pm 0.8 \mathrm{Ma}$ (Elming et al. 1999). Interruptions in volcanic activity allowed weathering and erosion.

(2) During the second stage, large-scale explosive eruptions dominated, producing non-welded andesitic ignimbrites (Unit IV). This sequence also includes Plinian fallout deposits (small dacite to rhyolite lava flows and welded to non-welded silicic ignimbrites; Unit II).

(3) The next stage started with the formation of silica-rich andesite lava flows and minor fallout deposits (Unit V). At the end of this period, a large volume of basaltic lavas erupted, locally accompanied by small fallout deposits. Young basaltic eruptions were dated at around $17 \mathrm{Ma}$ (Ehrenborg 1996; Elming et al. 2001). The emplacement of basalt dykes was interpreted as a result of coeval tectonic extension within the edifice. Their formation is related to the evolution of the NE-SW- and $\mathrm{SE}-\mathrm{NW}$-striking fault systems. During this stage, the growth of the main part of the La Luna Volcano occurred on the gentle slopes of the Santa Lucía stratoshield. We interpret the zones of widespread lateritization at the top of Unit $\mathrm{V}$ as resulting from weathering during a long break in volcanic activity.

(4) Lahars (Unit VI) evacuated large volumes of lava blocks from the upslope parts of the radial valleys. Voluminous lahar deposits have the form of rings of coarse breccias along the rim of the present caldera. Similar deposits were found in the southern rim of the Las Lajas caldera. It can be speculated that a possible preceding eruption might have been responsible for the collapse of the Santa Lucía Volcano. Nevertheless, no younger volcanic products have been documented in the area.

(5) Since the Miocene, volcanic rocks have been deeply weathered and locally strongly eroded. Movements on the two main fault systems (NE-SW and SE-NW) partially destroyed the caldera after the last strong eruption. The weakness and instability of volcanic edifice was a logical reason for the subsequent giant rockslide in its southern part. Fracturing by extensional and gravitational faulting resulted in a gravitational collapse at the southern part of the caldera (Baroň et al. 2008). Simultaneously, smaller rockslides and landslides occurred inside the caldera walls.

Lithological cross-section of the Santa Lucía Volcano is interpreted as typically exposing the upper part of the Coyol Group. Our studies show that there are six major lithological units. Similar units can be distinguished in the surrounding volcanoes of Las Lajas, La Luna and San Lorenzo. However, a detailed comparison of lithologies of the individual volcanoes reveals numerous differences. Individual volcanoes grew independently and their volcanic activity was different.

\subsection{Genesis of ignimbrites}

Deposits of lithic-rich pyroclastic flows are mostly nonwelded with clast- or matrix-supported texture, not only in the area but also in other adjacent regions. Most ignimbrites in the study area show homogeneous textures, the eutaxitic texture in fairly welded rocks is rather rare. Most lithic fragments reveal dacitic composition.

The homogeneous, slightly welded to non-welded "Fonseca-type" ignimbrite facies of the Santa Lucía caldera forms a thick mantle covering the oldest coarse "Boaco-type" ignimbrite. The Las Lajas dacitic ignim- 
brites, products of a supposed great caldera-forming explosion, are less widespread, younger than eutaxitic ignimbrites from the San Lorenzo caldera SW of Camoapa.

Non-welded facies is common in the "Fonseca-type" ignimbrite, whereas more welded types with compacted and deformed components were found in the San Lorenzo and Las Lajas volcanic products. There is no difference in the age; more likely it is a result of deposition at distinct emplacement temperatures (lower at the Santa Lucía Volcano). Welding compaction in the Las Lajas and San Lorenzo facies suggests hot emplacement temperatures (above glass-transition temperature), high volatile contents and probably stronger load pressure.

\section{Conclusions}

- The Santa Lucía Stratoshield Volcano, located in Central Nicaragua (Boaco district), was active during Miocene times. During the Pleistocene and Holocene, it has been strongly modified by erosion and tectonic events triggering mass movements.

- The volcano was built on a basement of silica-rich ignimbrites (Boaco-type). Four/five distinct evolutionary stages were recognized, some of them separated by erosional surfaces and/or weathering horizons. During the Miocene, volcano edifice was growing as a composite andesite cone. The second stage was dominated by large explosive eruptions producing non-welded andesite ignimbrites. In the late evolutionary stage, silica-rich andesitic and basaltic lava flows accompanied with minor tephra fallout deposits were mainly formed. Voluminous lahar flows (Unit VI) represent the end of volcano evolution: a part of them may have formed in connection with the youngest Las Lajas Volcano.

- The erosional relicts of neighbouring volcanoes (La Luna, San Lorenzo and Las Lajas) are remarkably similar in rock composition and textures. However, the lithological sequences of these volcanoes are to a large degree independent, indicating temporal changes in volcanic activity.

Acknowledgements. The authors wish to thank Benjamin van Wyk de Vries and two anonymous reviewers for a critical review of the manuscript. We are also grateful to Vladislav Rapprich for editorial work. Šárka Benedová is thanked for the electron microprobe assistance. This work was conducted with the financial aid of the project of geological research of hazardous processes in Nicaragua, provided by the Czech Geological Survey in cooperation with the Instituto Nicaragüense de Estudios Territoriales (INETER) under the financial support of the Ministry of the Environment and the Ministry of Foreign Affairs of the Czech Republic, project No. RP 6/07 in 2007-2009.

\section{References}

Baroñ I, Novotný R, Kernstocková M, Buriánek D, Havlíček P, Hradecký P, Melichar R (2008) Geomorphic, structural and paleostress analysis of a Quaternary giant slope failure near Boaco and Santa Lucía (Nicaragua, Central America). In: JABOYEDOFF M (ed) Collection of Abstracts from the Congress Slope Tectonics 2008, $15-16^{\text {th }}$ February 2008. University of Lausanne

Buriánek D, ŽáčKová E, Hradecký P, Havlíček, Novotný R, BAROŇ I (2008a) Mapa geologico del territorio del Boaco, Nicaragua $1: 50,000$ (in Spanish)

Buriánek D, Hradecký P, Havlíček, Novotný R, Baroñ I, ŽÁčKovÁ E, LeXA J, Echaverry M, Obando T. (2008b) Mapa geologico del territorio del Santa Lucia, Nicaragua $1: 50,000$ (in Spanish)

Boynton WV (1984) Cosmochemistry of the rare earth elements: meteorite studies. In: HENDERSON PE (ed) Rare Earth Element Geochemistry. Elsevier, Amsterdam, pp 63-114

Carr mJ, Saginor I, Alvarado GE, Bolge Ll, Lindsay FN, Milidakis K, Turrin BD, Feigenson MD, Swisher CC III (2007) Element fluxes from the volcanic front of Nicaragua and Costa Rica. Geochem Geophys Geosyst 8, doi 10.1029/2006GC001396

Cas RAF, Wright JV (1987) Volcanic Successions Modern and Ancient: a Geological Approach to Processes, Products and Successions. Allen \& Unwin, London, pp 1-528

Duncan RA, Hargraves RB (1984) Plate tectonic evolution of the Caribbean region in the mantle reference frame. In: BonINI WE (ed) The Caribbean-South American Plate Boundary and Regional Tectonics. Geological Society of America, Boulder, pp 81-94

Ehrenborg J (1996) A new stratigraphy for the Tertiary volcanic rocks of the Nicaraguan Highland. Geol Soc Am Bull 108: 830-842

ELMING SÅ, RASMUSSEN T (1997) Results of magnetotelluric and gravimetric measurements in western Nicaragua, Central America. Geophys J Int 128: 647-658

Elming SÅ, Widenfalk L, Rodriguez D (1999) A palaeomagnetic study and $\mathrm{K}-\mathrm{Ar}$ age determinations of Tertiary volcanic rocks in Nicaragua. In: ELMING S, WidENFALK L, RoDRIGUEz D (eds) Geoscientific Research in Nicaragua, a Swedish Nicaraguan Joint Project During the Period 1981-1991. Luleå University of Technology, Luleå, Sweden, pp 1-19

Elming SÅ, LAyer P, Ubieta K (2001) A palaeomagnetic study and age determinations of Tertiary rocks in Nicaragua, Central America. Geophys J Int 147: 294-309

FunK J, Mann P, McIntosh K, Stephens J (2009) Cenozoic tectonics of the Nicaraguan depression, Nicaragua, and Median Trough, El Salvador, based on seismic-reflection profiling and remote-sensing data. Geol Soc Am Bull 121: $1491-1521$ 
GARAYAR JS (1972) Geología y depósitos de minerales de la región de Chontales y Boaco, Informe 11. Archivo de INETER, Managua pp 1-89 (in Spanish)

Hodgson G (1972) Mapa geológico de la hoja topográfica La Libertad. Catastro e Inventario de Recursos Naturales, Managua, Nicaragua (in Spanish)

HRADECKÝ P (2006) Tertiary ignimbrites in Central America: volcanological aspects and lithostratigraphical correlation proposal. Krystalinikum 31: 11-23

Hradecký P, Buriánek D, Havlíček P, Baroñ I, Hrazdíra P, Novotný R, Š́evčí́ J, Echaverry M, Obando T, Fifernová M, KunceOvá E (2008) Mapa geologico y de riesgos naturales, Boaco, Nicaragua. Czech Geological Survey, Prague, pp 1-109 (in Spanish)

Irvine TN, BARAgAR WRA (1971) A guide to chemical classification of the common volcanic rocks. Canad J Earth Sci 8: 253-248

JANOUŠEK V, FARROW CM, ERBAN V (2006) Interpretation of whole-rock geochemical data in igneous geochemistry: introducing Geochemical Data Toolkit (GCDkit). J Petrol 47: 1255-1259

Jordan BR, Sigurdsson H, Carey S, Lundin S, Rogers RD, Singer B, Barquero-Molina M (2007a) Petrogenesis of Central American Tertiary ignimbrites and associated Caribbean Sea tephra. In: MAnN P (ed) Geologic and Tectonic Development of the Caribbean Plate in Northern Central America. Geological Society of America Special Papers 428: 151-179

Jordan BR, Sigurdsson H, CARey SN, Rogers R, Ehrenborg $\mathrm{J}$ (2007b) Geochemical variation along and across the Central American Miocene paleoarc in Honduras and Nicaragua. Geochim Cosmochim Acta 71: 3581-3591

KRETZ R (1983) Symbols for rock-forming minerals. Amer Miner 68: 277-279

Leake BE, Wooley AR, Arps CES, Birch WD, Gilbert MC, Grice JD, Hawthorne FC, Kato A, Kisch HJ, KrivoviCHEV VG (1997) Nomenclature of amphiboles: report of the Subcommittee on Amphiboles of the International Mineralogical Association Commission on New Minerals and Mineral Names. Canad Mineral 35: 219-237

Le Bas M J, Le Maitre R W, Streckeisen A, Zanettin B (1986) A chemical classification of volcanic rocks based on the total alkali-silica diagram. J Petrol 27: 745-750

McBirney AR, Williams H (1965) Volcanic History of Nicaragua. University of California Press, Berkeley and Los Angeles, pp 1-65

Morimoto N (1988) Nomenclature of pyroxenes. Mineral Mag 52: 535-550

Peccerillo A, Taylor SR (1976) Geochemistry of Eocene calc-alkaline volcanic rocks from the Kastamonu area, northern Turkey. Contrib Mineral Petrol 68: 61-81

Plank T, BAlzer V, CARR M (2002) Nicaraguan volcanoes record paleoceanographic changes accompanying closure of the Panama gateway. Geology 30: 1087-1090

Rogers RD, Mann P, Emmet PA, Venable ME (2007) Colon Fold Belt of Honduras: evidence for Late Cretaceous collision between the continental Chortis Block and intraoceanic Caribbean Arc. In: MANN P (ed) Geologic and Tectonic Development of the Caribbean Plate in Northern Central America. Geological Society of America Special Papers 428: 129-149

SAGINOR I (2008) Volcanic History of Western Nicaragua and Geochemical Evolution of the Central American Volcanic Front. Unpublished PhD. thesis, The State University of New Jersey, New Brunswick, pp 1-133

Tyburski SA, Gordon MB, Mann P (1991) Caribbean Basin framework, 2: northern Central America. AAPG Bull 75: 1-584

Weyl R (1980) Geology of Central America (second edition). Gebrüder Bornträger, Berlin-Stuttgart, pp 1-371

Winchester JA, Floyd PA(1977) Geochemical discrimination of different magma series and their differentiation products using immobile elements. Chem Geol 20: 325-343 